\title{
ALK-positive large B-cell lymphoma
}

INSERM

\section{Source}

INSERM. (1999). Orphanet: an online rare disease and orphan drug data base. ALKpositive large B-cell lymphoma. ORPHA:364043

Anaplastic lymphoma kinase (ALK)-positive diffuse large B-cell lymphoma is a very rare variant of diffuse large B-cell lymphoma (DLBCL; see this term) mainly affecting middleaged immunocompetent men and characterized by a consistent primary involvement of lymph nodes (mainly in the cervical and mediastinum lymph nodes) and with infrequent extra nodal involvement of the bone marrow and other extra-nodal sites (head and neck region, liver, spleen, and gastrointestinal tract). It has an aggressive disease course, and is associated with a poor prognosis. 